\title{
SOSIALISASI BASIC INVESTMENT “MENGENAL PASAR MODAL BAGI KAUM MILENEAL"
}

\author{
Rendy Mirwan Aspirandi \\ Universitas Muhammadiyah Jember \\ rendymirwanaspirandi@unmuhjember.ac.id
}

\begin{abstract}
ABSTRAK
Galeri Investasi BEI yang berjumlah 500 tersebut salah satunya berada di Universitas Muhammadiyah Jember (UM Jember). GI BEI UM Jember diresmikan pada tahun 2017. Umur yang telah menginjak 3 tahun ini, GI BEI UM Jember terus berperan aktif dalam melaksanakan edukasi pasar modal di tengah-tengah masyarakat. GI BEI yang berjumlah 500 tersebut salah satunya berada di Universitas Muhammadiyah Jember (UM Jember). GI BEI UM Jember diresmikan pada tahun 2017. Umur yang telah menginjak 3 tahun ini, GI BEI UM Jember terus berperan aktif dalam melaksanakan edukasi pasar modal di tengah-tengah masyarakat. Berdasarkan hasil observasi lapangan pada GI BEI UM Jember terdapat beberapa permasalahan yang berkaitan dengan proses sosialisasi pengetahuan bidang pasar modal. Berikut ini permasalahan sosialisasi pengetahuan bidang pasar modal yang dapat menjadi salah satu faktor penghambat proses inklusi bidang pasar modal. Pada sesi diskusi terdapat beberapa pertanyaan yang ditanyakan oleh peserta pengabdian masyarakat yang menanyakan berkisar mengenai risiko dan cara berinevstasi di pasar modal. GI BEI UM Jember yang telah memiliki kerjasama dengan Bursa Efek Indonesia dan Perusahaan Sekuitas yaitu Kresna Sekuritas dapat mewadahi peserta pengabdian masyarakat yang berkeinginan langsung berinvestasi di pasar modal.
\end{abstract}

Kata Kunci: Galeri Investasi, Investor, UM Jember 


\section{PENDAHULUAN}

Galeri Investasi Bursa Efek Indonesia (GI BEI) merupakan wadah yang memfasilitasi para calon inevstor dan investor mendapatkan ilmu pengetahuan berinvestasi di Pasar Modal. GI BEI wadah penting untuk memotivasi calon investor dalam berinvestais di pasar modal (Malik, 2017). GI BEI merupakan kerja sama three partied antara Perguruan Tinggi, Bursa Efek Indonesia dan Perusahaan Sekuritas. Kerja sama ini bertujuan utama untuk mensosialisasikan wawasan berinvestasi produk-produk di pasar modal.

Sesuai dengan Undang-undang Nomor 8 Tahun 1995 tentang Pasar Modal mengatur mengenai mekanisme pelaksanaan berinvestasi di pasar modal. Pada peraturan tersebut disinggung mengenai peran keberadaan $\mathrm{GI}$ BEI yang sangat penting dalam menyediakan sarana belajar berinvestasi bagi masyarakat. GI BEI akan menjadi kepanjangan tangan dari BEI dalam peningkatan literasi bidang pasar modal.

GI BEI di Indonesia sudah berjumlah 500 pertanggal 14 Desember 2020 (https://www.indonesiaexpose.co.id, 2020). Jumlah tersebut merupakan jumlah yang cukup banyak. GI BEI yang berjumlah ratusan tersebut diharapkan semuanya berperan aktif dalam menunjang terwujudnya masyarakat Indonesia yang teredukasi pasar modal.

GI BEI yang berjumlah 500 tersebut salah satunya berada di Universitas Muhammadiyah Jember (UM Jember). GI BEI UM Jember diresmikan pada tahun 2017. Umur yang telah menginjak 4 tahun ini, GI BEI UM Jember terus berperan aktif dalam melaksanakan edukasi pasar modal di tengah-tengah masyarakat.

GI BEI UM Jember telah berdiri 3 tahun sejak tahun 2017. Lokasi yang berada di lantai 2 Gedung A Universitas Muhammadiyah Jember. Lokasi di lantai 2 ini mengakibatkan GI BEI UM Jember kurang diketahui oleh masyarakat di luar kampus. Sehingga jumlah investor yang terdaftar di GI 


\section{Jurnal ABDIMAS INDEPENDEN}

Vol. 2, No. 2, November 2021

BEI UM Jember dipandang masih sangat sedikit dengan perbandingan 1:10.

Jumlah investor yang terdaftar di GI BEI UM Jember hanya sekitar 150 orang (Narasumber GI BEI UM Jember).

Kurangnya jumlah investor yang terdaftar di GI BEI UM Jember menunjukkan masih kurang optimalnya inklusi di bidang pasar modal. Inklusi bidang pasar modal ini memang dipandang masih kurang secara nasional, maka dari itu dibutuhkan edukasi terlebih dahulu sebelum memasarkan produk-produk pasar modal (https://www.liputan6.com, 2020). Oleh karena itu, berbagai sosialisasi pasar modal di GI BEI UM Jember masih dianggap sangat perlu.

\section{Gambar 1}

Peresmian Galeri Investasi Bursa Efek Indonesia Universitas Muhammadiyah Jember

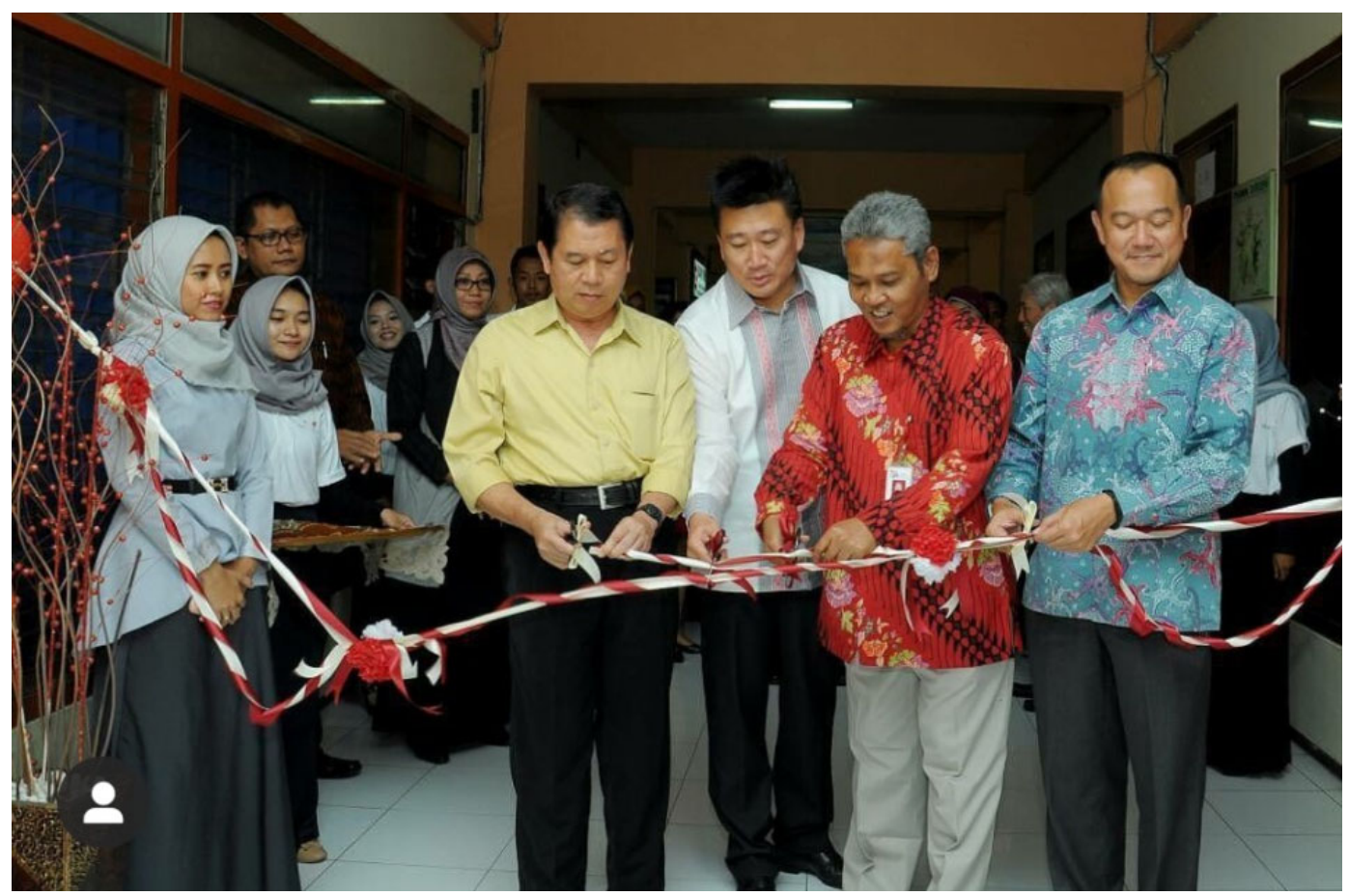

Sumber: Instagram kspm_umjember 


\section{Gambar 2}

Kondisi Depan Galeri Investasi Bursa Efek Indonesia Universitas Muhammadiyah Jember

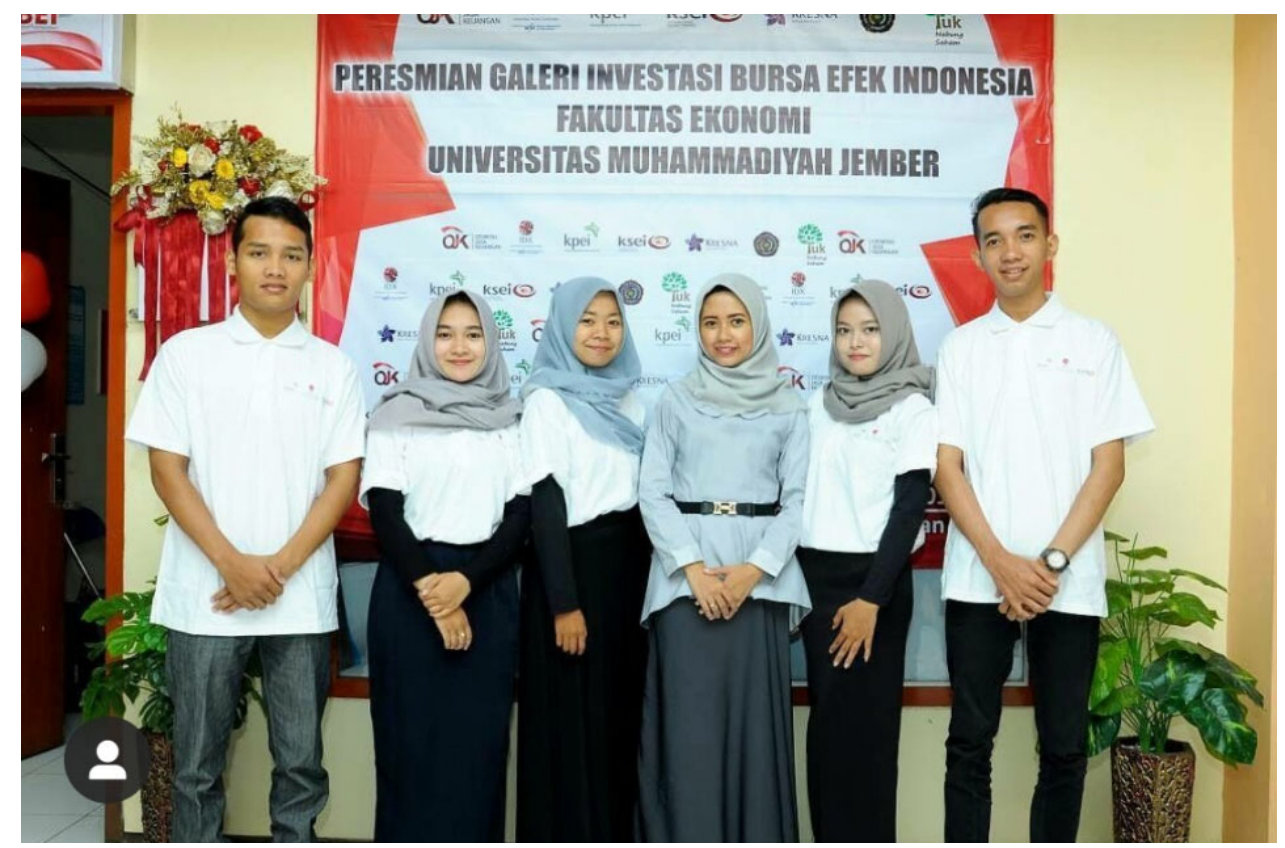

Sumber: Instagram kspm_umjember

GI BEI UM Jember yang patut untuk diperjuangkan keberadaannya dalam ikut berperan dalam aktivitas inklusi pasar modal. GI BEI UM Jember harus tetap dibantu dalam pelaksanaan sosialisasi di bidang investasi di pasar modal. Pelaksanaan sosialisasi ini salah satu caranya adalah melalui aktivitas pengabdian masyarakat.

Renstra Pengabdian UM Jember 2016-2020 berorientasi pada terwujudnya masyarakat Islam yang sebenar-benarnya yang berkeadilan dan berkemakmuran jasman dan rohani serta diridlai Allah SWT. Orientasi tersebut selaras dengan tujuan pendirian Persyarikatan Muhammadiyah, PTM dan UM Jember. Adapun fokus pengembangan Renstra Pengabdian UM Jember dituangkan dalam 10 peta jalan (roadmap) bidang-bidang unggulan sebagai berikut :

1. Pengembangan Model Pendidikan Keatif dan Peningkatan Kualitas Hidup Islami

2. Pengembangan Ekonomi Kreatif Berbasis Potensi Lokal

3. Pengembangan Infrastruktur yang ramah lingungan dan berkelanjutan 
4. Pengembangan Energi Terbarukan dan Konversi Energi

5. Pengembangan Tata Kota yang dapat menyelesikan permasaahan dan mengelola sumberdaya dengan dukungan TIK.

6. Pengembangan Capacity Building Masyarakat Pandalungan.

7. Pengembangan Politik Pemerintahan Lokal.

8. Pengembangan Teknologi Kesehatan

Tema pengabdian masyarakat yang akan dilaksanakan dengan dana mandiri ini adalah "Basic Investment (Mengenal Pasar Modal Bagi Kaum Mileneal)". Berkaitan dengan renstra pengabdian UM Jember tahun 20162020, maka tema dan judul ini masuk dalam renstra bidang unggulan kedua. Pengembangan Ekonomi Kreatif Berbasis Potensi Lokal. GI BEI UM Jember butuh bantuan dalam hal sosialisasi wawasan atau pengetahuan bidang pasar modal.

Berdasarkan hasil observasi lapangan pada GI BEI UM Jember terdapat beberapa permasalahan yang berkaitan dengan proses sosialisasi pengetahuan bidang pasar modal. Berikut ini permasalahan sosialisasi pengetahuan bidang pasar modal yang dapat menjadi salah satu faktor penghambat proses inklusi bidang pasar modal.

1. GI BEI UM Jember masih minim narasumber tetap untuk proses sosialisasi pasar modal.

2. Pengetahuan Sumber Daya Manusia pada Kelompok Studi Pasar Modal (KSPM) GI BEI UM Jember masih minim dan perlu dikembangkan.

Atas permasalahan tersebut maka diperlukan suatu solusi agar terdapat perbaikan dalam peran inklusi bidang pasar modal. Solusi yang dapat diberikan yaitu dengan melakukan sosialisasi "Basic Investment (Mengenal Pasar Modal Bagi Kaum Mileneal)". Hasil dari sosialisasi ini adalah beberapa peserta memahami mengenai dasar-dasar yang harus dipahami sebelum melaksanakan investasi di pasar modal. 


\section{METODE KEGIATAN}

Kegiatan pengabdian dilakukan di GI BEI UM Jember yang beralamatkan di Jalan Karimata No. 49 Kecamatan Sumbersari Kabupaten Jember tepatnya di Gedung A Lantai 2 Universitas Muhammadiyah Jember. Kegiatan dilaksanakan secara daring (online). Pelaksanaan akan dijadwalkan sesuai susunan acara dengan memanfaatkan media online, yaitu: Aplikasi Zoom Meeting. Sasaran kegiatan pengabdian ini adalah Calon investor dan investor GI BEI UM Jember memiliki wawasan tambahan mengenai dasar-dasar berinvestasi di pasar modal.

Jenis kegiatan dalam pengabdian ini adalah sosialisasi "Basic Investment (Mengenal Pasar Modal Bagi Kaum Mileneal)". Pelaksanaan kegiatan Pengabdian Pada Masyarakat ini dilakukan dengan menggunakan metode ceramah dan diskusi. Adapun sistematika pelaksanaan kegiatan pengabdian ini adalah sebagai berikut:

1. (Metode Ceramah):

Peserta diberikan dasar-dasar dalam berinvestasi di pasar modal dengan materi lengkap beserta pengalaman berpraktik di pasar modal

2. (Metode Diskusi):

Peserta diberikan kesempatan untuk mendiskusikan permasalahan yang berkaitan dengan pengetahuan pasar modal.

\section{HASIL DAN PEMBAHASAN}

Materi Pengabdian Masyarakat berkaitan dengan sosialisasi pengetahuan dasar dalam berinvestasi di pasar modal. Materi yang diberikan kepada para peserta adalah pengetahuan tentang efek, landasan hukum syariah tentang berinvestasi di pasar modal dan cara berinvestasi. Penyampaian materi secara daring (online) melalui Aplikasi Zoom Meeting. Efek bersifat syariah memiliki syarat:

1. Efek Utang: obligasi syariah

2. Efek Ekuitas: saham syariah 
3. Tidak boleh margin trading

4. Tidak boleh melakukan short sell

Landasan mengenai Pasar Modal Syariah:

1. Fatwa No. 20 Tahun 2001 tentang penerbitan reksa dana syariah.

2. Fatwa no. 40 Tahun 2003 tentang pasar modal dan pedoman umum penerapan prinsip syariah di bidang pasar modal.

3. Fatwa no. 80 Tahun 2011 tentang Penerapan Prinsip Syariah dalam Mekanisme Perdagangan Efek Bersifat Ekuitas di Pasar Reguler Bursa Efek.

4. Peraturan OJK no. 15/POJK.04/2015 tentang penerapan prinsip syariah di pasar modal

Materi berlanjut pembahasan sekilas mengenai analisis yang dapat dilakukan untuk mengetahui saham-saham yang bagus. Analisis yang dapat dilakukan adalah analisis fundamental dan analisis teknikal. Analisis fundamental adalah analisis mengenai kinerja perusahaan yang menerbitkan saham yang bersangkutan (Dwialesi \& Darmayanti, 2016). Analisis Teknikal adalah analisis yang menilai kinerja historis suatu harga, volume dan transaksi saham di pasar modal (Abidin et al., 2016). Kedua analisis tidak terpisahkan satu sama yang lain. Analisis utama yang dilakukan adalah analisis fundamental yang menentukan perusahaan berkinerja baik atau buruk. Analisis pelengkap adalah analisis teknikal yang digunakan dalam mengambil peluang membeli dan menjual saham pada harga yang tepat (pemaksimalan return saham).

Pada sesi diskusi ada beberapa peserta yang menanyakan mengenai dasar berinvestasi di pasar modal. Pertanyaan pertama ditanyakan oleh Fadilatul Munawarah yang menanyakan Apa risiko yang akan dihadapi oleh investor di pasar modal?. Risiko yang akan dihadapi di pasar modal ada 2 jenis, yaitu: risiko turunnya harga saham dan risiko likuidasi terhadap perusahaan. Risiko turunnya harga saham merupakan risiko yang sangat umum dialami oleh investor ketika berinvestasi di pasar modal. Risiko ini 
seakan-akan tidak dapat di hindari oleh semua investor. Persiapan psikologi investor harus baik untuk menghadapi segala ketidkpastian harga saham di pasar modal. Risiko yang paling besar yang akan dihadapi oleh investor adalah risiko likuidasi. Risiko likuidasi adalah risiko yang akan dihadapi investor ketika perusahaan yang menerbitkan saham mengalami kebangkrutan. Kedua risiko ini dapat diminimalisir dengan melakukan analisis fundamental yang mendalam di sebuah saham perusahaan yang diterbitkan di pasar modal.

Pertanyaan kedua ditanyakan oleh Rofik Musanif Maulana yang menanyakan Bagaimana mekanisme kita dapat berinvestasi saham?. Mekanisme kita supaya dapat berinvestasi saham adalah mendaftarkan diri kita ke Galeri Investasi yang telah bekerja sama dengan Bursa Efek Indonesia dan Perusahaan Sekuritas supaya kita mendapatkan SID (Single Investor Identification). SID inilah yang dijadikan dasar kita membuka RDN (Rekening Dana Nasabah) dan hak akses pada Aplikasi Trading Perusahaan Sekuritas.

\section{KESIMPULAN DAN SARAN}

Kegiatan Program Pengabdian Masyarakat ini dilaksanakan melalui aktivitas sosialisasi mengenai "Basic Investment (Mengenal Pasar Modal Bagi Kaum Mileneal)". Pelaksanaan dilakukan secara daring (online) melalui Aplikasi Zoom Meeting. Antusiasme peserta pengabdian masyarakat ini cukup tinggi. Selain acara diadakan secara daring karena pada masa Pandemi Covid-19, materi yang disajikan sangat menarik mengenai dasardasar investasi di pasar modal.

Pada sesi diskusi terdapat beberapa pertanyaan yang ditanyakan oleh peserta pengabdian masyarakat yang menanyakan berkisar mengenai risiko dan cara berinevstasi di pasar modal. GI BEI UM Jember yang telah memiliki kerjasama dengan Bursa Efek Indonesia dan Perusahaan Sekuitas 
yaitu Kresna Sekuritas dapat mewadahi peserta pengabdian masyarakat yang berkeinginan langsung berinvestasi di pasar modal.

Pengabdian masyarakat ini sebaiknya lebih digalakkan pelaksanaannya, karena literasi di bidang pasar modal masih sangat kurang. Proses pengabdian selanjutnya sebaiknya lebih melibatkan banyak kalangan, baik dari kaum mileneal maupun orang dewasa yang sudah bekerja di instansi-instansi.

\section{UCAPAN TERIMAKASIH}

Kami tim pengabdian masyarakat mengucapkan banyak terimakasih kepada Ibu Gardina Aulin Nuha, SE., M.Akun. selaku Direktur Galeri Investasi Bursa Efek Indonesia Universitas Muhammadiyah Jember karena telah diberikan izin dalam melakukan kegiatan pengabdian ini kepada para investor GI BEI UM Jember. Kami juga mengucapkan terimakasih kepada adik-adik KSPM UM Jember yang telah membantu terselenggaranya kegiatan pengabdian masyarakat ini.

\section{DAFTAR PUSTAKA}

Abidin, S., Suhadak, \& Hidayat, R. R. (2016). Pengaruh Faktor-faktor Teknikal Terhadap Harga Saham. Jurnal Administrasi Bisnis.

Dwialesi, J., \& Darmayanti, N. (2016). Pengaruh Faktor-Faktor Fundamental

Terhadap Return Saham Indeks Kompas 100. E-Jurnal Manajemen Universitas Udayana.

https://www.indonesiaexpose.co.id. (2020). Pengembangan Pasar Modal

Indonesia: Apresiasi BEI untuk Negeri di Tahun Kebangkitan Investor Ritel Dalam Negeri - Indonesia Expose. https://www.indonesiaexpose.co.id/2020/12/14/25019/ https://www.liputan6.com. (2020). OJK Dahulukan Literasi Sebelum Kejar Inklusi Pasar Modal - Bisnis Liputan6.com. 
https://www.liputan6.com/bisnis/read/4427607/ojk-dahulukanliterasi-sebelum-kejar-inklusi-pasar-modal

Malik, A. D. (2017). Analisa Faktor - Faktor Yang Mempengaruhi Minat Masyarakat Berinvestasi Di Pasar Modal Syariah Melalui Bursa Galeri Investasi UISI. Jurnal Ekonomi Dan Bisnis Islam (Journal of Islamic Economics and Business). https://doi.org/10.20473/jebis.v3i1.4693 